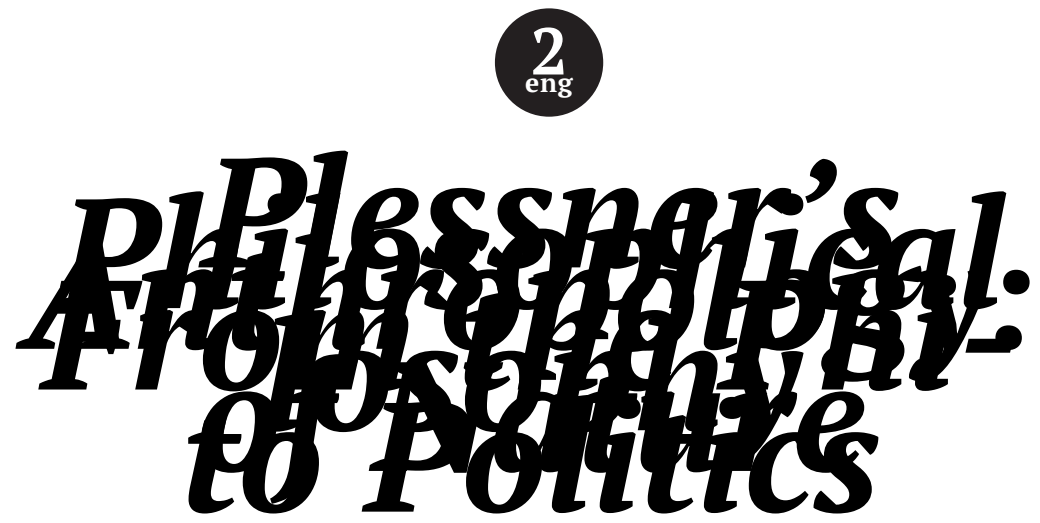

Michael Lewis

Senior Lecturer in Philosophy

University of Newcastle upon Tyne,

NE1 7RU, United Kingdom

E-mail:Michael.lewis@newcastle.ac.uk

\title{
Plessner's Philosophical Anthropology: From the Philosophy of Nature to Politics ${ }^{1}$
}

\begin{abstract}
:
One of the most pressing tasks of contemporary thought is to think together the two discourses which have most fully developed the two poles of anthropogenesis, biological life and the symbolic legal order:

Lacanian psychoanalysis (often in conjunction with Hegelian and

${ }^{1}$ Earlier versions of certain parts of this essay were given as talks at the University of Dundee on Wednesday 20 November, 2019 and at the University of Newcastle upon Tyne on Friday 6 December, 2019. Many thinks to those who participated, and in particular to the organisers, Frank Ruda and Sinéad Murphy, for their ongoing support, as well as the two reviewers for Stasis for their supportive and generous comments.
\end{abstract}


Marxian dialectics) and (anti-dialectical) post-Foucauldian biopolitics. Both, we propose, could be described as forms of "philosophical anthropology." This essay investigates the work of Helmuth Plessner, to illuminate the fundamental issues that confront any attempt to specify the human being on the basis of a philosophy of nature. It does so in such a way as to pay heed equally to both the natural sciences and the human sciences.

This will mark the first step in an attempt to specify the way in which one might bring together psychoanalysis and biopolitics in order to pursue the same task.

\section{Keywords:}

Helmuth Plessner, Jacques Lacan, Paolo Virno, Carl Schmitt, philosophical anthropology, man, double body, double aspect, eccentric positionality, philosophy of nature, philosophical biology, philosophical zoology, psychoanalysis, biopolitics, anthropocene, world, environment, world-forming, relativism, historicism, absolutism, interpretation, hermeneutics, open question, incompleteness

\section{The Anthropocene and Anthropology}

If we are indeed in the Anthropocene epoch, then it is as well to understand what we mean by anthrōpos. The Anthropocene, just like post-humanism, trans-humanism, inhumanism, and whatever else we are told has come to put us in our place, loses all sense if the meaning of that which it purports to overcome has not been clarified in advance.

That said, the Anthropocene does not simply overcome man, but rather demonstrates how one (cultural) part of the (natural) whole can exert such an influence upon its unfolding that it may derail the very course of natural history. Humanism and post-humanism, the philosophy of spirit and the philosophy of nature, the human sciences and the natural sciences are somehow sublated here. Perhaps in this regard the theory of the Anthropocene comes closest to what we should like to urge upon the other theories we have grouped together with it: a realization that one cannot understand what it means to overcome man if one does not first investigate what man is - what it must be such that it is susceptible, perhaps, of being overcome.

This, in effect, was the investigation pursued by Philosophical Anthropology, a movement inspired by Friedrich Nietzsche and the life-philosophy (Lebensphilosophie) that burgeoned in his wake, in Wilhelm Dilthey, Henri Bergson, and their progeny - phenomenology 
and existentialism most prominently. For all that Nietzsche exhausted himself in preparing for the overman, the now obscure figures who took up the legacy of a certain phenomenology of life remained devoted to man: the animal that promises to be something but is yet to be determined. Thus, they advocated what Carl Schmitt would describe as an "anthropology of evil" - negation, lack (1996: 61).

But what became of Max Scheler, Helmuth Plessner, and Arnold Gehlen? Why has their work, while remaining somehow classic in a certain - somewhat drab - tradition of German hermeneutic critical theory, never truly been reclaimed by the most theoretically progressive strands of Continental European philosophy?

We shall devote ourselves here to an examination of the way in which the philosophy of nature, anthropology, and politics are bound together in the work of Helmuth Plessner, with particular attention to the manner in which his thought moves from nature to the political. This will help us to identify and, if possible, avoid some of the dead-ends into which this attempt might in general risk being led, and hence some of the challenges that confront a rapprochement between biopolitics and psychoanalytic theory. This conjunction would involve the attempt to speak not just retrospectively of a life subordinated to law (biopolitics), but also of a living body that becomes amenable to the incursions of law in the first place (psychoanalysis), and it remains one of the most pressing tasks of contemporary philosophy.

\section{Science and Phenomenological Philosophy}

Helmuth Plessner's Levels of Organic Life and the Human (Die Stufen des Organischen und der Mensch) published in 1928 (1975, 2019), ${ }^{2}$ outlines a "phenomenological" way in which to distinguish between the three "levels" of the living world: plant, animal, and human. Plessner's "philosophical biology" or "philosophy of nature" is phenomenological insofar as it aims to identify the conditions that must be met in order for an organism to appear to us as living - to be adjudged as "living" by a conscious entity. Philosophy deals with appearance; science with reality, ${ }^{3}$ and science remains in a certain

\footnotetext{
${ }^{2}$ Hereafter only the cited publication date for all Plessner references will be given. A detailed publication history of Plessner's works can be found in the reference list and additional bibliography.

${ }^{3}$ Plessner describes these intuited forms as "phenomenological states of affairs," "phenomenological indicators of life," which he distinguishes from "ontological statements" (Plessner 2019: 118, cf. 122). The relation between philosophy and science will nevertheless turn out to be much closer than it seems at first glance: "we may also concede an ontological value to the indicative characteristics of the organic” (Ibid: 118).
} 
sense secondary to philosophy, since even biologists, Plessner tells us, rely on a non-empirically derived "intuition" of what counts as living: "He [the biologist] is guided by sensory intuition [the faculty thematized by phenomenological philosophy] [...]. His empirical research, then, as concerns the stock of specifically biological categories, rests on premises that can only be analyzed by the philosopher" (Plessner 2019: 108-9). ${ }^{4}$

\section{Positionality and the Center}

One of the notions that Plessner uses to determine the phenomenological essence of the living being is "positionality" (Positionalität). Something appears to be "posited" by life: an actual or virtual center that will unify in various ways the multiplicity of the animal's organs into one organism. The organic world is differentiated into levels by the different manners in which this unification is achieved, and the degrees to which it is successful. Life is distinguished from non-life by means of a certain "relationship of a body [in the sense of a 'center'] to its boundary” (Plessner 2019: 113), its perceptible "Gestalt" (Ibid: 115-16). Individuated entities have boundaries that demarcate them from what they are not - this is the case for inorganic nature as well as organic nature; but the living being's boundary is not merely something that remains separate from it; the relation between an organism and its boundary is akin to that which relates center and periphery.

Even non-organic entities can evince the qualities of a Gestalt, but in the non-organic, the wholeness of an entity's appearance is not perceived as having been made into a whole by a hidden center. There is nothing "posited" behind the (unified) multiplicity; whereas in our experience of living things, there is (Ibid: 149). ${ }^{5}$

\section{Dual Aspect of the Living Being}

In the living being, whole and parts become somewhat distinct, and hence one can speak of this wholeness, or at least its source, as

${ }^{4}$ The distinction between levels of being is explicitly intended not to be an empirical scientific distinction: "A purely empirical distinction between plants and animals will always run into great difficulties because it will not be able to simply pass over the existence of transitional forms" (Plessner 2019: 203).

${ }^{5}$ One source of this unwieldy term, "positionality," by way of a Latinisation, is J. G. Fichte's "positing" (setzen) - the "I posits the non-I" - the body relates to itself as to another, as to something outside of itself, and hence is stretched between itself and its self, itself and its own future in the sense of that which it will become (Plessner 2019: 120-21). 
being represented in a distinct center - one that is "posited." This goes some way toward explaining another of the names that Plessner gives to the phenomenological peculiarity of the organism: the "dual aspect” (Doppelaspekt) of its body (2019: 149). Plessner explicitly aligns this with Edmund Husserl's distinction between the physical body (Körper) and the lived body (Leib) (Ibid: 219-20). This in turn corresponds to the distinction for which Plessner was to be famous: having a body and being a body. The organism is described as being a center that has its peripheral organs in the way that a workman has his tools (Ibid: 220). Plessner understands the central core of the organism (the living body, Leib) to constitute the initial germ of a "self" or "subjectivity": he describes it as the "subject of having" (Ibid: 149). ${ }^{6}$ Subjectivity thus develops from the organic realm of "life" (Leben) as the result of a splitting within the organism, that prises apart the physical body, which is decentered and objective, from the lived body, which constitutes the absolute subjective center for all of the animal's experiences.

Once formed, the center leaves itself, to seek the periphery, before returning. In this return, it creates a certain "feedback" loop that amounts to a primordial reflexivity: Plessner thus feels licensed in speaking of "a self-referentiality of the system" (Ibid: 121). The parts are referred back to the center, allowing the center to produce a "representation" of the whole organism, gathering the data that its organs supply.

Plessner thus provides us with a materialistic rendition of Martin Heidegger's "ecstatic existence," a notion which was being developed at exactly the same time from a standpoint for the most part distinct from zoology and anthropology: the actual body's standing beyond its self and pressing ahead into the realm of non-corporeal, ideal potentials.

\section{Human Continuity and Discontinuity}

If animals are already divided at the level of their body, and if therefore the distance that allows for reflection is already present there, then what distinguishes the human from the animal?

To avoid presupposing the privilege of man that metaphysics will have assigned him (reason, self-consciousness, the ability to say "I," law, culture, desire...) and to remain at the level of a body that is more or less material, Plessner will speak of the "eccentric position"

6 "[W]e have arrived at the crucial point in our investigation where the possibility of the development of consciousness emerges in the first place" (Plessner 2019: 148). 
(exzentrische Position) of the human with respect to its own body. ${ }^{7}$ The human is eccentric or decentered in relation to its positionality, which implies the ever-present possibility of a discrepancy between its center and its periphery.

Of the animal and the human, Plessner says the following:

In this respect man is inferior to the animal since the animal does not experience itself as shut off from its physical existence, as an inner self or I, and in consequence does not have to overcome a break between itself and itself, itself and its physical existence. The fact of an animal's being a body does not cut it off from its having one. It does indeed live in this separation [...]. The switch from being to having, from having to being, which the animal constantly performs, does not in its turn present itself to the animal, nor, consequently, does it present any difficulty [kein 'Problem'] to it. (Plessner 1970: 38; 2016: 242) ${ }^{8}$

The separation between lived center and periphery - being and having - "causes no problems" for the animal, and as a result, the switch between being and having is not "presented" to it. The animal body is an instrument to be mastered, but one might surmise that the lack of infantile delay in the achievement of this mastery is what allows the gap to be plastered over so quickly that it goes unnoticed in all but a very sick or dying animal; Plessner tells us that the animals "achieve this instrumentality without being aware of it and without first having to find a relation to it" (Plessner 1970: 41).

For humans, on the other hand, neoteny retains us in the childhood state of a discrepancy and lack of mastery: we are a "lived body in a physical body [als Leib im Körper]. From the day of his birth on, everyone must come to terms with this double role" (Ibid: 34; 2016: 238). The rent in the human's "double body" is too gaping, and too slow in being bridged to remain invisible or irrelevant for

${ }^{7}$ Eccentric also in relation to the environment. This amounts to distinguishing, as Gehlen will, between the animal's relation with a single finite environment and the human's dwelling in any number of potentially infinite worlds: "Eccentric to his environment [Umwelt], with a prospect on a world [Welt] [...]" (Plessner 1970: 87).

${ }^{8}$ But this is also the source of a deficit on the part of the animal: "The lack of inhibition which makes the animal superior to man in control determines at the same time its restriction to the role that happens to be biologically assigned to it. It cannot come upon the idea [...] to try out with its body something not immediately prescribed by its motor functions and instincts. Things may go ever so well with real donkeys; yet they never venture out onto the ice" (Plessner 1970: 38).

When the original text is included in the quotation, I provide a reference first to the English translation and then to the German original. 
the functioning of the organism: Plessner speaks of "eccentricity" as "the unbridgeable gap between man and himself" (Ibid: 7). It is this distance that makes man a stranger to himself, this chasm that sparks off an unending chain of interpretations that the human being will make of itself, as it attempts precisely to know itself. This amounts to saying that, for Plessner, as for most philosophical anthropologists, there is a biological - or quasi-biological - level of the human that stands prior to the Delphic exhortation.

The significance of the phenomena of laughter and crying is that they are bodily events that reveal this gap at its most unbridgeable: "laughing and crying are forms of expression of a crisis precipitated in certain situations by the relation of a man to his body (a relation which is a form of behavior as well and not a piece of fixed machinery on which one need only rely [as it is with animals]), then laughing and crying are revealed as genuine, basic possibilities of the universally human" (Ibid: 11).

Laughter and crying force us to move beyond the anthropology that we find in metaphysics, centered as it is around the superiority of man consequent upon his possession of logos in the sense of reason and speech (Ibid: 38). But the real question is how both possibilities - the rational power of sovereign self-possession, and the abject powerlessness of self-distance-can exist in the same entity. For that reason, in the end, nothing depends on the supposed proposition of a human "monopoly" on laughter; laughter and crying demonstrate a response made by man to his own self and to his environment that effectively indicates a failure of the very faculty that metaphysics was most proud to assign him:

Laughing and crying are forms of expression which, in the full sense of the words, only man has at his disposal. At the same time, these forms of expression are of a kind to which this monopolistic situation is in strange contrast. For one thing they have nothing in common with language and expressive movement [Sprache und Gebärden, speech and gesture], by which man shows himself superior to other living creatures [...]. Laughing and crying are not found in the same stratum, are not on the same level, as language and expressive movement. To laugh or cry is in a sense to lose control; when we laugh or cry, the objective manipulation of the situation is, for the time being, over. (Plessner 1970: 23; 2016: 225)

Laughter and crying thus remain close to those moments at which a certain rational or spiritual mastery of the natural irrational body slackens, and human life veers toward its own nutritive life, which 
takes over completely in such cases as the loss of consciousness in fainting or sleep, and the almost automatic "vegetative processes" of "blushing, turning pale, vomiting, coughing, sneezing" (Ibid: 24). And yet they are not mere reactions to a situation, but rather "interrupt the normal course of life," and are easier to induce voluntarily than the quasi-automatic reactions of vegetal existence.

Plessner thus asks how these two instances of power and powerlessness can belong together in one entity-language and work on the one hand, and the incapacitation of laughter and tears on the other: "The relation to intelligible order [language, reason, metaphysics] which man lays claim to and attests by his activity must somehow also make laughing and crying possible [...]. The matter under discussion is [...] how the strangely opaque mode of expression of the human body must be understood from the relation of man to his body" (Ibid: 25-26).

Laughter and crying take place, for Plessner, when a spiritual mastery of the body reaches its limit. This mastery, and hence the metaphysical conception of man as a soul governing its body as a master does his slave, are undermined at a single stroke, in a peal of laughter. Such a metaphysical theory on its own will have misled us into thinking that - precisely because the body could always, in normal, specifically human situations be subdued by the spirit - there is fundamentally no discrepancy between "spirit" and "body" and hence the latter can never altogether escape the former's mastery.

In fact, this is the case not for man, but for the animal, in whose body the gap between being and having is crossed so expertly that it remains blissfully unaware of it. But it also leaves the animal unable truly to laugh or cry in the sense that is crucial to Plessner. But in the case of the human we do indeed witness such a being out of kilter, a primal split at the origin of the human - the disparity and concomitance of impotence and potency with respect to the body. In laughter and crying, a bodily activity exceeds, if only by a narrow margin, our spiritual control: "laughing and crying attest to an incalculable emancipation of bodily events from the person. In this disproportion and willfulness, we surmise, lies what is truly revelatory in the phenomena” (Ibid: 33 ).

The environment makes a demand on us that we are unable to respond to with the magisterial use of the body that we have, and so, since "we necessarily lose the reference in terms of which we could find a relation to our physical existence," we respond with laughter or crying, in which the body expresses the fact that it has strayed beyond the control of the subject (Ibid: 150). These two forms of helplessness just are the expression of this disconnection within the body, the decentering or eccentricity between its posited center and 
its now adrift periphery - a return perhaps, each time, to our infantile Hilflosigkeit. For the sake of this revelation, it is important that we not lose control altogether: in the "blacking-out of consciousness," "the human unity of the person is destroyed" - man becomes a plant and forgets even to dream of being human; whereas, "with laughing and crying the person does indeed lose control, but he remains a person, while the body, so to speak, takes over the answer for him. With this is disclosed a possibility of cooperation between the person and his body, a possibility which usually remains hidden because it is not usually invoked" (Ibid: 33). The memory of the human is not altogether lost, but stands apart from us, just out of reach.

What distinguishes humans from animals is not the double body itself, torn between Leib and Körper, being and having, but an awareness of this distance. This consciousness is brought about when the sundering reaches an extreme of eccentricity, and thus a certain flexibility in the way that we relate to our body: either as subject, the center of the world, or just one more material object within a decentered universe (Ibid: 149).

\section{The Political Interpretation of Being and Having: Power and Powerlessness}

If the linguistic aspect of the human is somehow a subordinate compensation for a primal lack (the gap that separates being from having and wreaks its specifically human havoc while also granting the human being its specific powers), then what are we to say of the biological basis for the other defining feature of man: the political? ${ }^{9}$ How are we to move, in other words, from a philosophy of nature to a politics?

For Plessner, the question of a political anthropology, as opposed to a philosophical anthropology, is: "to what extent does politics - the struggle for power in human relations among individuals, groups and associations, nations and states - belong to the essence of the human? (Plessner 2018: 3). The political is defined by Plessner at least in part according to Carl Schmitt's definition: "[the political sphere] is given in the primeval life relationship of friend and enemy" (Ibid: 6).

Thus it can be seen that far from what might seem to be the case with certain contemporary advocates of biopolitics, the Aristotelian definition of man as zōon politikon is not taken for granted, and is indeed grounded biologically.

\footnotetext{
${ }^{9}$ On the notion of "compensation" in Plessner, a term more usually associated with Gehlen, see Dybel (2018: 127n5). This notion, alongside references to J.G. Herder, who may be reckoned among its inventors, is prominent in Plessner's later work.
} 
To engineer a political anthropology, Plessner rethinks his (quasinaturalistic) definition of the human as an eccentric wavering between mastery and dispossession, in terms of power. The objective corporeal body that we have is thus conceived as a moment of our powerlessness, enmeshing us within a nature whose laws we do not posit; while the lived body that we are allows us to take control, assume power, partly thanks to its capacity to "form worlds" of an infinite and (historically and geographically) variable extent, in contrast to the finite natural "environments" of the animal.

Thus, eccentric positionality is here reconceived at the political level as the entwinement between the powerless and the powerful, nature and history, those (natural-scientific) facts which can be "explained," and the human decisions and interpretations which can only be (hermeneutically) "comprehended" or "understood": "Eccentric position [... is] the interlocking of the open possibility of understanding the human with the possibility of explaining the human without being able to make the limits of comprehensibility [die Grenzen der Verständlichkeit] coincide with the limits of explainability [Erklärbarkeit]" (Plessner 2018: 84; 1981: 231).

Thus, now that the human animal has been fully immersed in culture, anthropology must enter the circle of self-interpretation that every cultured human being undertakes, and attempt to describe it phenomenologically - in the very terms employed by that culture and that human being. The production of a world in thought, speech, and work takes place on no ground at all, save the human being's own decision, and this necessitates a recourse on the part of the anthropologist to a hermeneutic approach. This in turn demands that we confront the specter of historical and cultural relativism, which threatens the absolute truth of any interpretation of the human and its culture, including Plessner's own.

Finally, in an unexpected manner, Plessner's lengthy engagement with the dispute concerning interpretation and its foundation will lead us to touch upon the problem of the incompleteness of reality, from a novel perspective.

\section{Dilthey and Historicism}

Human culture is understood by Plessner to be a projection of a certain life form, a self-interpretation on the part of a specific group of human beings: a decision as to what matters, which must be shared by whoever wants to partake of that culture. What in the natural world would be taken by science to be "facts" are here understood rather as "decisions": 
Only in this consideration of history does the orientation of the question of the essence of the human leave to historical facts their originary importance as decisions about the essence of the human. This is how history is divested of its merely empirical character, of an empiricity that is incapable of obtaining any insight into essences $[\ldots]$. This is [...] what Dilthey asserted against an age of resurgent, nonhistorical apriorism - which, even if it refuses to acknowledge it, is rationalism resurrected and is, at its base, a reactive absolutization of European value systems. (Plessner 2018: 26)

Plessner's great predecessor (Heidegger's too), Wilhelm Dilthey had asserted (a certain reflective) historicism against (a spurious) ahistoricism. The point of Dilthey's approach was neither cede altogether to an a priori ahistorical rationalism nor unreservedly to embrace an a posteriori historical empiricism. This remained the case even if the former attempted to incorporate history by positing a logic or philosophy of history, for this very positing evacuated the historical of its historicity, its eventuality; the latter on the other hand was excessive in dispensing with Reason and the a priori altogether, so as to lose itself in the flux of historical events. Instead one must place one's self firmly in the realm of hermeneutics and its circle: always already in the midst of things in their (factual) existence, but none the less able to tease out, in an always unfinished process, their essence. Intelligibility is not given by a priori categories imposed from outside of history, but rather is found already inherent within it, although in an obscure fashion that stands in need of clarification. The task of hermeneutics is to provide an explicit elucidation of an interpretation that has already implicitly been given.

The agency that both produces and clarifies its own meaning is human life, "factical" historical life, from which the separation between empirical and transcendental, historical and ahistorical, genetic and structural, emerges: as Plessner puts it, the suprahistorical ideal emerges "from the creative power of the historical human," the intelligible and the sensible splitting apart in their eruption from an original excluded middle:

History, such as it comes to be understood by being conveyed to the present that investigates it, has to be made 'possible' in itself. This is the genuine meaning of the word life [Leben], which Dilthey uses terminologically, a life that drives its meaning from out of itself [seine Bedeutung aus sich hervortreibt] and makes itself understand [sie sich selber zu verstehen gibt, gives itself to understand] this meaning, 
that manifests the conditions for the possibility of its history in the first place. (Plessner 2018: 37; 1981: 174)

Life produces significance only in the form of a differential totality of interrelating significations: a world. World-formation amounts to the production of a set of values and cultural laws which then come to be accepted as eternal: thus the universal and a priori is understood in fact to emerge from historical life in a way that undermines the framework which conceptualizes human life in terms of an opposition between experience and its ahistorical transcendental conditions.

In its subjective experience of itself and its objective products (subjective and objective spirit, Geist, in G. W. F. Hegel's terms), the human being finds itself always already in the midst of implicitly interpreted data; never in possession of a fully present and thoroughly intelligible "given" (a "fact" beneath "values"), and thus never standing, as a subject, in some sovereign position able to shape experience in the sense of a pure empiricity, in a purely transcendental a priori fashion. Rather, it comes upon itself and its products, and even nature itself, in an already interpreted historical form.

Experience is thus understood as neither determined by a priori strictures nor reducible to empiricist conceptions of facts, but rather to be comprised of facts that are also "decisions," interpreted facts, shaped and articulated so as to become worlds.

\section{The Debate Between Relativism and Absolutism}

This world-formation exists as a compensation for the human being's primordial lack of a limited animal environment: it thus has its source in the quasi-biological situation of eccentricity, which renders man's world as groundless or unfathomable (unergründlich) as he himself is. ${ }^{10}$ This fact in itself seems to suggest that any cultural world will be entirely relative to the form of life that projected it, and the time and place in which it was produced.

10 The term, "unfathomability” (Unergründlichkeit) possibly stems from Georg Misch's “unfathomable 'wherefrom' [unergründlichen Woher] of the human” (Plessner 2018: 25 ; 1981: 160), but with the qualification that it also refers to the future: "the unfathomable that-toward-which [unergründlichen Woraufhin] of our decisions" (decisions of interpretation as well as individual and political decisions, one may presume) (Ibid: $45 ; 183)$. Neither an uninterpreted ground nor a fully determinate meaning will ever be reached. In this regard, Plessner also speaks of "indeterminacy" (Unbestimmtheit) (cf. Ibid: 49; 188): "According to the principle of the relation of indeterminacy toward itself or the principle of the open question [...]" (Ibid: 85), and the "bottomlessness" or "groundlessness of so-called existence" (die Bodenlosigkeit der sog. Existenz) (Ibid: 65; 1981: 206). 
Dilthey's philosophy set itself precisely to carry the humanspiritual sciences (Geisteswissenschaften) beyond the debate between relativism and absolutism - the former in the guise of historicism, which was taken to mean any account of the human being and its culture that affirmed that each of these accounts remained merely relative to its historical moment. It did so, according to Plessner, in the following way: the very idea of a universality that would tether the proliferation of relativities to a single Archimedean point, is itself relative - it emerges from a particular history that originates in a particular location, and that is ancient Greece. But at the same time, this modern relativization of all worldviews is itself immediately transformed into its opposite, a universality: the very idea of a relative (culturally dependent, formed) world is a modern European one, which we then extend (as a universal relativization) to all cultures. We thereby relativize our own world, but immediately absolutize the idea that worlds as such are relative and that human beings are world-forming creatures: "indifferent to religious and racial differences, then the standard of this universal perspective precisely obliges us not only to bring our culture to the 'heathens' as an absolute, but also to relativize our culture and our world over against other cultures and worlds" (Plessner 2018: 14).

It seems that it is only this dialectical European standpoint that is capable of mediating between different political positions and worldviews and hence of avoiding simple war - for both a pure self-assured absolutism and a pure relativism for which there could be no criteria with which to decide on the rightness of any particular worldview, nor any possibility of being rationally compelled to modify one's interpretation seem destined to result in the violence that takes up where language and negotiation break off.

In any case, this war is always a possibility in any genuine politics and irrupts when the latter is pushed to its most extreme point, according to Carl Schmitt, who looms large here:

This is the only thing the human who has assumed the European principle of open immanence and of understanding the human from out of life and oriented toward life can do: despite and in its particularity, assert the universally binding position of the being-human that is truly and authentically so only in this position; despite the monadic individualization and closedness of ethnic, philosophical, political positions against one another, creatively assert the continuous medium that connects them all, the medium that had come into view as a possibility in the Greek discovery of mathematical general validity. (Plessner 2018: 76) 
Dilthey's philosophy of life, and Plessner's in its wake, thus propose to solve the enigma of relativism by affirming the world-formative character of man - that is itself recognized at a particular historical and geographical moment - as absolute (cf. Plessner 2018: 77). Thus we have a dialectic - of absolutism and relativism - in which each individual interpretation of the human declares itself absolute, first of all; then one particular interpretation (the modern European, the perspective of a certain anthropology that is also Plessner's) declares the relativity of each of these interpretations; finally, this opposition between absolutism and relativism is sublated when this relativity becomes aware that in asserting relativism universally, it is asserting an absoluteness of relativity: "the human can experience what the human is only through history [i.e., relativistically]. Within this perspective, however, the philosophy of life assumes more than this because it knows about its own relativity" (Ibid: 77, emphasis added).

\section{The Incompleteness of (Historical) Reality and the Questionable Subject}

The anthropology that amounts to the absolutization of relativity, the universal proclamation that man is a world-forming entity, is Plessner's own. It affirms that the human is an entity lacking a ground, unfathomable in the sense that there is no absolute, ahistorical, a priori accessible ground for any of its cultural productions. It finds itself in a world that has already been shaped by the history of a particular geographically situated culture. It is incapable either of providing or of finding an ultimate foundation that would render this interpretation an absolute and ahistorically true one.

This bottomless unfathomability means that the properly human gesture is inevitably that of questioning, a probing which pursues this ever-retreating ground-raised to an art and a way of life in Philosophy. Everything in human life is thus eminently questionable-indeed, the human itself may be defined absolutely as an eternally "open question" (eine offene Frage), a question to itself (Plessner 2018: 61; 1981: 201), as are the products of human spirit: "The objects of the humanities are put into question as, in principle, unfathomable in the sense that they can never be understood completely. They are open questions" (Ibid: 43;181).

This is the sense in which, for Plessner (and Dilthey) historical reality itself remains incomplete: "not until we take the unfathomable to be binding [...] does the intellectual world [die geistige Welt] come into view as a reality that is not completed [unabgeschlossene] in our living present" (Ibid: 43; 182). 
Reality itself, beings as a whole, are an unfinished project: they cannot form a totality, and we might say that, in Plessner's case, this is precisely because the human being has arisen (from nature) so as to punch a hole in them.

\section{Relativity as the Condition of Absolutization; Perspective as the Condition of Objectivity}

Not that the negativity of non-completion is a barrier to a vision of the whole, as the Nietzschean tradition, which in this respect seems to culminate in Lacanian psychoanalytic ontology, seems to think; indeed, what the Husserlian phenomenological tradition will have taught us, and what it certainly taught Plessner, was that this incomplete perspectival character of reality was precisely the precondition for objectivity, for absoluteness. ${ }^{11}$

Plessner himself licenses us in deploying this phenomenological idea to reconsider the dialectic of relativism and absolutism, since he explicitly uses this Husserlian language to speak of the absolute truth of the European perspective (relativism): "historical relativism finally becomes conscious of its own relativity and, after a period of historicist despair, learns to understand this relativity as the condition of genuine objectivity [echten Objektivität]" (Plessner 2018: 47; 1981: 185).

What are the implications for this at a political level, in the context of the struggle between the only apparently relative worldviews of entire peoples or cultures?

\section{The Politics of World-Forming}

The definition of man - and so of anthropology as such - is immediately political in the sense that the human is said to be uniquely possessed of a certain power, and this is the capacity to form historical worlds.

Naturally, belonging to a certain world involves sharing it with others, at least potentially, and thus one is inducted into a political sphere. But this whole situation imposes constraints: Plessner defines "politics" at one point as the "fashioning and assertion of human power," as if this openness of the human's potential-to-be were both a promise and a threat, a threat precisely because the promise is unlimited and in need of limitations - shaping: "[b]ecause it remains undecidable whether primacy belongs to philosophy or anthropology, both are

11 " $[\mathrm{T}]$ his fixed order [of non-present elements] [...] represents [...] the absent itself [das Abwesende selbst]. It is on this order that objectivity [Gegenständlichkeit] or the genuineness [Echtheit] of things rests" (Plessner 2019: 251; 1975: 270). 
opened onto life or onto the human in its unfathomable power [seiner unergründlichen Macht] and inserted into the same perimeter that is taken up by politics as autonomous fashioning [selbstmächtige Gestaltung] and assertion of human power" (Plessner 2018: 74; 1981: 218).

In short, Plessner asserts that philosophy, anthropology, and politics find their common source in the principle of unfathomability ("of life and the world"), "the open ground of powerfulness" (Ibid: 62).

The ability to form a world, in which man's own being is writ large, is limitless and yet tempered by the laws imposed by the political realm: this is a precondition for belonging to a polis in the first place. In order to share in a world, one which will always already have been in existence, one's interpretation of that cultural world must be to some extent compatible with that of one's fellow citizens: this sets limits to an individual's powers arbitrarily to concoct a private world of their own.

At the same time, as soon as one belongs to such a shared world, the risk of conflict and war, in the struggle for hegemony, imposes itself at a supra-individual level: "home-worlds" come into conflict with "alien-worlds," to use phenomenological terminology once again.

\section{Familiar and Foreign: Closed and Open - Plessner's Politics and Beyond}

Plessner will already have referred his definition of the political to Carl Schmitt, and this anthropological understanding of politics as involving the power to shape worlds and then to become involved in a power struggle for the dominance of a particular worldview projected collectively by a certain "people," comes to be described in literally Schmittian terms as the relation between "friend" and "enemy." ${ }^{12}$ These may be defined as those who belong to the polis,

${ }^{12}$ Schmitt avers that there are two possible anthropologies at the root of political thought in the sense of a theory of the state and the decisive power of the sovereign that stands at its head: "Every political idea in one way or another takes a position on the 'nature' of man and presupposes that he is either 'by nature good' or 'by nature evil"” (Schmitt 2005: 56, cf. Ibid: 66); "One could test all theories of state and political ideas according to their anthropology [...] [,] whether man is a dangerous being or not, a risky or a harmless creature" (Schmitt 1996: 58).

Schmitt proposes that those political theories which ground themselves upon an anthropology of goodness are not in fact political theories at all, for they ultimately imply a distrust of the state which the innate goodness of man ultimately renders redundant. These so-called political theories that oppose the state include anarchism and liberalism: both must-explicitly or implicitly-rely on an anthropology of goodness. Authoritarian theories of a powerful state, on the other hand, must presuppose an anthropology of evil. Given these respective doctrines of human nature, and since neither anarchism nor liberalism can provide a genuinely political theory, 
"[w]hat remains is the remarkable and, for many, certainly disquieting diagnosis that all genuine political theories presuppose man to be evil, i.e. by no means an unproblematic but a dangerous and dynamic being" (Schmitt 1996: 61).

On this point, Schmitt, in a note to the 1932 edition of the Concept of the Political, identifies Plessner's anthropology as attributing evil to man's nature: "Helmuth Plessner, who as the first modern philosopher in his book Macht und menschliche Natur [Political Anthropology] dared to advance a political anthropology of a grand style, correctly says that there exists no philosophy and no anthropology which is not politically relevant, just as there is no philosophically irrelevant politics. [Here Schmitt's interpretation becomes slightly more tendentious:] He has recognised in particular that philosophy and anthropology, as specifically applicable to the totality of knowledge, cannot, like any specialised discipline, be neutralised against irrational life decisions [...]. If one bears in mind the anthropological distinction of evil and good and combines Plessner's 'remaining open' with his positive reference to danger, Plessner's theory is closer to evil than to goodness” (Schmitt 1996: 59-60). Thus Plessner's evil anthropology provides us with something like a genuine political theory.

Schmitt goes on to align this evil with his characterization of the political as defined by the possibility of (public, not private) opposition between friendly and enemy groups: "Because the sphere of the political is in the final analysis determined by the real possibility of enmity, political conceptions and ideas cannot very well start with an anthropological optimism" (Schmitt 1996: 64). In the political arena, friend and enemy signify "the utmost degree of intensity of a union or separation, of an association or dissociation" (Schmitt 1996: 26). Schmitt glosses this point in the following way: "the other, the stranger" is one so distantly separated from us, or so different, that no mediation is possible between us: he is "existentially something different and alien, so that in the extreme case conflicts with him are possible. These can neither be decided by a previously determined general norm nor by the judgement of a disinterested and therefore neutral third party" (Ibid: 27).

Who counts as a friend and who an enemy is decided precisely by the state itself, in its sovereign power: "the state as an organised political entity decides for itself the friend-enemy distinction” (Schmitt 1996: 29-30). As the decision to group individuals in this oppositional manner is the "most extreme possibility" for the political - broadly speaking, war - we can speak of this scission as being made primarily in a "critical situation, even if it is the exception," and thus the decision to divide a multitude into an oppositionally defined pair may be described as "sovereign" (Ibid: 38) since, as the classic definition that opens the Political Theology has it: "[s]overeign is he who decides on the exception," where "exception is to be understood to refer to a general concept in the theory of the state, and not merely to a construct applied to any emergency decree or state of siege" (Schmitt 2005: 4). Schmitt explicitly relates this sovereign decision on the exception to the friend-enemy distinction in the following passage: "in the orientation toward the possible extreme case of an actual battle against a real enemy, the political entity is essential, and it is the decisive entity for the friend-or-enemy grouping; and in this (and not in any kind of absolutist sense), it is sovereign. Otherwise the political entity is nonexistent" (Schmitt 1996: 39).

To be political is to be an entity that is capable of setting up the polemos between two groups which are henceforth, on the basis of that decision, rendered oppositional; and that the state has the sovereign power with which to do this renders the state a truly political entity: "That the state is an entity and in fact the decisive entity rests upon its political character" (Schmitt 1996: 44).

Given the necessity for enmity in the political, and as a consequence of the sovereign political decision, one cannot think the political whilst also adopting an anthropology of goodness (Schmitt 1996: 64). Thus, in a Schmittian manner is the opposition between a home-world and an alien-world explained by means of political anthropology. 
who share in the general interpretation, and those who do not - an infinity of others which Plessner here seems to speak of as intimating the "bottomless real" itself:

There is always already a limiting of the native sphere against the open foreign sphere, a limiting that is artificial and yet natural [...], a limiting that must permanently be drawn, renewed, changed [...]. In permanent breaks, the human thus conquers its environment from the world between environment and world, between the homely zone of familiar references and relations of signification that have "always already" ["immer schon"] been understood and the uncanny reality of the bottomless world [der unheimlichen Wirklichkeit der bodenlosen Welt]. (Plessner 2018: 57-58; 1981: 197-98)

Plessner also refers to the latter (Welt, stricto sensu, as opposed to the limited and closed Umwelt) as "the open world of the bottomless real" (der offenen Welt des bodenlosen Wirklichen) (Ibid: 58;198).

In one of his earliest works, The Limits of Community, subtitled A Critique of Social Radicalism from 1924, this radicalism being "the radicalism of community" (Plessner 1999: 81), Plessner attributes the undesirability of the latter to a certain anthropology:

One can express the problem of a critique of social radicalism in the following formula: Is it possible to eliminate force from an ideal social life of humans? Is it possible to integrate without force, restraint and artificiality the physical dimension of man's being with his personality as soul and spirit, considering that the physical dimension forces man wherever he goes to employ means of force of the basest kind? (Plessner 1999: 61)

This leads Plessner to a curious argument in favor of society (Gesellschaft) rather than community (Gemeinschaft), which militates against full communication and sharing, fusional or otherwise, and installs a certain distance, impersonality and the possibility of concealment between citizens (cf. Plessner 1999: 85). This all takes place on the basis of a certain, as yet undeveloped, "anthropology of

In general, the passage from the "social" to the "political" by way of a coalescence of many struggles around a single "hegemonic" struggle is seized upon and transformed into a rigorous technical opposition by Ernesto Laclau and Chantal Mouffe (cf. 2014: xii). Instead of "friend and enemy," Laclau and Mouffe will speak more neutrally of "antagonism." And this will have been by no means the only case of a left-wing resumption of Schmitt's work, nor of a recuperation of the anthropological classification for leftist ends. Paolo Virno remains a model for us here (cf. infra). 
evil": the human animal needs containing: "Radicalism $-[\ldots]$ as the conviction of the thorough transformation of societal life relations that are based on force into communal life relations that are based on nonviolence - is exposed at that moment as a lie" (Ibid: 62).

If Plessner's works lend themselves to a Schmittian interpretation, then we might wonder whether the political consequence of his later thought is that the state must ultimately be understood as forcefully constraining the individual to a certain "indirectness," "tempering" the free expression of the human being's power in precisely the way of a strong authoritarian politics (Plessner 1999: 61).

And yet: the work of the Italian philosopher, of a broadly Marxist strain, Paolo Virno testifies to the ever-present possibility of another political conclusion, far from Schmitt's own, which may be drawn from the latter's texts against their will and contrary to their stated intention. Virno broadly accepts Schmitt's ideas concerning the relation between anthropology and politics, and yet immediately reverses their significance: specifically, he demonstrates that, in truth, an anthropology of evil can provide us with arguments in favor of a weak state, and even anarchism (cf. Virno 2008: 12ff). ${ }^{13}$ Thus, whatever conclusions Plessner himself might draw, the space remains open for a broader range of political positions than he perhaps suspected, each founding themselves upon the type of anthropology which the Weimar Philosophical Anthropologists promoted.

\section{Determination and Indetermination}

But let us precipitate a conclusion by moving to a level deeper than the potential political implications of philosophical anthropology, so as to examine some more fundamental problems.

There is a certain recurrent criticism of this anthropology of indeterminacy (or "evil"), or rather a caution that is advised with respect to it: if one is trying to say that the human being is of indeterminate essence, naturally (or at least in a retroaction of culture and its language and law upon nature such that the "in-" of negativity could be applied to nature at all), one must be careful not to make this indetermination into yet another determination. ${ }^{14}$

If we reify this indeterminacy in the case of man, this would be homologous with the ontological gesture of making the incompleteness of the symbolic universe into a truth that, precisely by being

\footnotetext{
${ }^{13}$ For more on Virno's background in Philosophical Anthropology, as well as his potential relationship with Jacques Lacan on a similar topic, cf. Lewis (2018).

${ }^{14}$ For a condensed account of the Lacanian version of this, see Lorenzo Chiesa (2016), and an explicitly Marxist version in Frank Ruda (2009).
} 
affirmed as absolutely true, paradoxically asserts just what it denies: completeness. This is because it affirms - and can only affirm - incompleteness from the transcendent standpoint of a metalanguage, or God's point of view, which by implicitly positing such a position of enunciation affirms the totality or completeness of the supposed non-totality that it surveys. By altogether exempting itself from "beings as a whole," it draws an oppositional boundary between itself and its other, thereby totalizing the other.

This was the mistake of metaphysics when it came, onto-theologically, to speak and think of beings (as such and) as a whole, pronouncing God dead without realizing that this very pronouncement could only be made from a divine standpoint, thus undermining its own enunciated content.

One should aim here to achieve the sophistication of a Hegel: Being is to be thought as indeterminate, but is not to be defined (determined) as indeterminate (Houlgate 2006: 263ff). Otherwise, at the level of the human and its anthropology, the notion of indetermination would play just the same role as any of the (positive) definitions of man which philosophy - and anthropology-have provided. It would introduce a completeness and fixity of man in the very act of asserting (from outside of his self-interpreting subjectivity) the ahistorical truth of his incompleteness and fluidity.

How might Plessner respond to such a criticism?

\section{Plessner's Response I: Biology}

In fact, Plessner addresses this idea explicitly: he affirms that the account of man's eccentric relation with his body is in fact a refraining from interpretation or determination. On our reading, this eccentricity (unfathomability, questionability) is the (biological - perhaps "undecidably" philosophical and anthropological) root of the hermeneuticphenomenological description of man as a world-forming and self-interpreting being, and hence a creature of a certain infinity. In light of this, Plessner states, "we have deliberately chosen to introduce a neutral concept like that of 'eccentric position' which refrains from every interpretation of what is essentially human" (Plessner 1970: 39). The root of man's infinite interpretability is not itself interpretive: this "neutral" conception of the human organism is intended to explain or at least condition all of those traits which have historically been assigned to man by his various self-interpretations.

In other words, Plessner attempts to account for the indeterminacy of the human essence, in the most minimal way possible, while still retaining the possibility of explaining that multiplicity of traits which is also nevertheless peculiar to the human. 
To translate this into the terms we have used above in speaking of political anthropology, this means that the European interpretation of man's essence is not just another (relative) interpretation, but the (absolute) condition for every interpretation. Only if we begin from this anthropology can we explain the whole constellation of other characteristics which have been attributed to man. ${ }^{15}$

\section{Plessner's Response II: Hermeneutics}

When we speak of the human being we are attempting to speak of "life" in the language of life, in its own terms; to speak of the finite historical human being as it interprets itself in the mirror of the cultural world which it projects. This Diltheyian project, issuing in hermeneutic phenomenology and the later hermeneutic philosophies of the twentieth century, comprises an attempt to describe a phenomenon in its own words, from "within," without importing a discourse from outside that would distort it, as a metalanguage subsuming many object-languages; or better put, as an objective account of an entity - the human being, for the most part - which is essentially both subjective and objective. Indeed we are already humans discoursing about humans, always already forbidden the possibility of metalanguage or the transcendent standpoint, and we are here simply attempting to enter this hermeneutic circle "in the right way" (as Heidegger put it). Phenomenological anthropology is trying as best it can to capture this very movement of self-definition or self-interpretation - to catch it "in the act" without assuming that there ever was a first, founding moment which we might regain by digging deep enough.

\section{Conclusion: Philosophical Anthropology Between Psychoanalysis and Biopolitics}

In light of what we have seen of Plessner's politico-philosophical anthropology, what more general lessons may be drawn from its unfolding for the pursuit of philosophy today?

In a way that runs parallel to the psychoanalysis of Jacques Lacan, it illuminates how the biological body can be inserted into a(n) (incomplete) symbolic order that raises the body to a new order

${ }^{15}$ Plessner even demonstrates the manner in which the many traits historically assigned to the human may be derived from his account (cf. Plessner 1970: 39), and this includes even the very desire to occupy some "absolute" position, ultimately divine, a wish stemming precisely from what Plessner calls the "utopian" position of having nowhere to stand (Ibid: 39ff). 
of life (or death), inducting it into the jurisdiction of the law, and subjecting natural life to supernatural prohibitions and imperatives.

The relation between psychoanalysis and German Philosophical Anthropology has been emphasized by a number of recent commentators, including Walter Seitter and Paweł Dybel.

Seitter attempts to demonstrate what he perceives as the role of a non-philosophical or only marginally philosophical "Humanmedizin," the medical treatment of specifically human pathologies, in the formation of Philosophical Anthropology in the late nineteenth and early twentieth centuries (Seitter 2015: 221). This includes not just Plessner himself (Ibid: 225) but precisely Sigmund Freud, who interpreted his own study of medicine as symptomatic of a more fundamental desire for knowledge of the human being. This leads Seitter to suggest that what philosophers may expect of psychoanalysis is precisely that it "make a contribution to the topic named "philosophical anthropology" (Ibid: 223). In support of this point, Seitter invokes Freud's assertion of the Oedipus complex as a universally human characteristic, which Claude Lévi-Strauss would later discover in a purely anthropological field in the guise of the "incest taboo." The necessity for such a complex was-according to Seitter (Ibid: 224) - traced back by Freud to the biological foundation of infantile "helplessness," which he explains in terms that would, at precisely the same time (1926), be deployed by Louis Bolk, and which were later spoken of as "neoteny," the natal prematurity of the human child and the prolonged retention of fetal traits (Ibid: 226-27).

Seitter makes it clear that the connection he draws between Freudian psychoanalysis and Philosophical Anthropology (Plessner, in particular) is made most clear by the work of Jacques Lacan and especially his earliest published texts (Ibid: 227):

Until 1949, his remarks on the Oedipus complex (as well as on the other complexes) were based on the tension [Spannung] between the biological and historicity [Geschichtlichkeit] [for according to Seitter he refused to think of the Oedipus complex as a natural universal, understanding it rather as historically specific and variable] - they thus stood in unwitting proximity with the theoretical style of Germanophone Philosophical Anthropology. (Seitter 2015: 230)

This may be so, but precisely the suggestion that Lacan moved away from a certain Freudian "biologism" or naturalism is only half the story, since the bio-zoological references of his earlier work remain foundational later on, and we must guard against any precipi- 
tate "de-naturalization" of the Lacanian rendition of psychoanalysis, that forgets these early moments in a kind of childhood amnesia.

Even though the names of Gehlen and Plessner seem not to appear in Lacan's œuvre, ${ }^{16}$ as Seitter acknowledges (2015: 228), he nevertheless shared a similar heritage, in the work of ethology and in particular in the discourses (embryology, physiology, psychology) that gave birth to the notion of neoteny in the nineteenth and twentieth century, from Louis Bolk to Adolf Portmann, both of whom are crucial influences and occasional interlocutors of the German anthropologists (cf. Dybel 2018: 127). Paweł Dybel, in his consideration of some of the early moments of Lacan's work, in terms of chronology and the order of foundation, finds these references to be crucial. In his elaboration of the notion of a mirror stage in childhood development, Lacan focused on the psychological effects of the perception of the complete physical body in the mirror, or in the Gestalt of the other human being in their reality. Ultimately a (temporarily) unified "ego" is formed by means of this "imaginary" (imagistic and phantastic) encounter.

Dybel's ultimate thesis has it that, in fact, Lacan is more of a philosophical anthropologist than Plessner himself, or a more adequate one, and that for the reason that he provides a more complete explanation of anthropogenesis. This is evinced most strikingly in his refusal to presuppose the reflexive form of the "I"; instead, he attempts to account for it on the basis of the "fragmented body" and the child's defensive reaction against it (Ibid: 133). Psychoanalysis traces the genesis of that living entity which, partly thanks to the identity that it acquires first of all by way of an "imaginary identification" with the apparently already totalized and individuated other (autre) in the "mirror stage," will eventually learn to name that identity in the universe of symbols - the symbolic order, the big Other (Autre) - by saying "I."

Thus, psychoanalysis would contribute a crucial element to philosophical anthropology itself; and, in turn, philosophical anthropology would, when it does not itself illuminate the mechanism and the effects of the living body's incorporation into the order of (symbolic) law, help to encourage a dialogue between psychoanalytic thought and that other great discourse of recent years, biopolitics. Biopolitics is the theory of life and law, of the power of life and what happens to it when it is subordinated to the political power of the law. Its congenital flaw seems to be that it generally approaches the question transcendentally from the standpoint of the finished product, rather than genetically from the perspective of biological life. This is also, as

\footnotetext{
${ }^{16}$ Both remain absent from the index appended to the English translation of the Écrits.
} 
we have seen, a temptation into which Lacanian psychoanalysis - or at least its philosophical interpretation - risks falling, but which it is also better able to resist, having always taken ontogenesis and phylogenesis more seriously than philosophy is wont to. Philosophical Anthropology stricto sensu can assist psychoanalysis by warning it against this temptation, and thus allowing it to press biopolitical philosophy in a naturalistic direction.

Which is as much as to say that in order to understand the relation between life and law, we need to understand life just as much as we understand law: and so we need the advice of biology, of the natural sciences, or of a philosophy of nature, just as much as we need the humanities or the social sciences (which help us to understand culture, history, and law).

In short, Philosophical Anthropology may assist both philosophy and psychoanalysis when it comes to clarifying the obscure relation that obtains between the natural and the human sciences, which has become such a pressing concern in philosophy; and those who got there first might well be able to act as our guides, but also to unite the two principal discourses of contemporary philosophy that have made the greatest strides in posing this problem.

\section{References}

Chiesa, Lorenzo (2016). “The Absence of the Sexual Relationship: A Transcendental Invariant of the Human Species?” Paragraph 39.1: 82-92.

Dybel, Paweł (2018). “Man, Animal, and Mirror. Origins of The Human 'I' According to Helmuth Plessner and Jacques Lacan.” Dialogue and Universalism 4:25-40.

Houlgate, Stephen (2006). The Opening of Hegel's Logic: From Being to Infinity. West Lafayette, IN: Purdue University Press.

Laclau, Ernesto, and Chantal Mouffe (2014). Hegemony and Socialist Strategy: Towards a Radical Democratic Politics, 2nd Ed [1985]. London: Verso.

Lewis, Michael (2018). “Virno's Philosophical Anthropology.” Journal of Italian Philosophy 1: 131-82.

Plessner, Helmuth (1970), Laughing and Crying: A Study of the Limits of Human behaviour [1941]. Trans. James Spencer Churchill and Marjorie Grene. Evanston: Northwestern UP.

Plessner, Helmuth (1975). Die Stufen des Organischen und der Mensch: Einleitung in die philosophische Anthropologie. 3rd edition. Berlin and New York: Walter de Gruyter.

Plessner, Helmuth (1981). Macht und menschliche Natur: Ein Versuch zur Anthropologie der geschichtlichen Weltansicht [1931]. Gesammelte Schriften, Vol. 5. Frankfurt am Main: Suhrkamp.

Plessner, Helmuth (1999). The Limits of Community: A Critique of Social Radicalism [1924]. Trans. Andrew Wallace. Amherst, NY: Humanity Books.

Plessner, Helmuth (2002). Grenzen der Gemeinschaft: Eine Kritik des sozialen Radikalismus. Frankfurt am Main: Suhrkamp.

Plessner, Helmuth (2016). Ausdruck und menschliche Natur. Gesammelte Schriften VII. Berlin: Suhrkamp. Originally published as Lachen und Weinen: Eine Untersuchung nach den Grenzen menschlichen Verhaltens (Bern: A. Franke, 1961 [1941]). 
Plessner, Helmuth (2018). Political Anthropology [1931]. Ed. Heike Delitz \& Robert Seyfert, trans. Nils F. Schott. Evanston, IL: Northwestern UP.

Plessner, Helmuth (2019). Levels of Organic Life and the Human: An Introduction to Philosophical Anthropology [1928]. Trans. Millay Hyatt. Editorial assistance from Phillip Honenberger. New York: Fordham UP.

Ruda, Frank (2009). “Humanism Reconsidered, or: Life Living Life.” Filozofski vestnik [Philosophical journal] XXX.2: 175-93.

Schmitt, Carl (1996). The Concept of the Political: Expanded Edition [1932]. Trans. George Schwab. Chicago: University of Chicago Press. Originally published as Der Begriff des Politischen (Munich: Duncker \& Humblot, 1996 [1932]).

Schmitt, Carl (2005). Political Theology: Four Chapters on the Concept of Sovereignty [1922]. Trans. George Schwab. Chicago: University of Chicago Press.

Seitter, Walter (2015). "Gemeinsamkeiten zwischen Freud, Plessner, Lacan: Physiologie, Essenzialismus.” Internationales Jahrbuch für philosophische Anthropologie 3.1: 221-32.

Virno, Paolo (2005). Motto di spirito e azione innovativa. Per una logica del cambiamento. Turin: Boringhieri.

Virno, Paolo (2008). Multitude: Between Innovation and Negation. Trans. Isabella Bertoletti, James Cascaito, and Andrea Casson. Los Angeles: Semiotext(e).

Virno, Paolo (2010). E così via, all'infinito: Logica e antropologia. Turin: Boringhieri.

\section{Additional works by Plessner}

Plessner, Helmuth (1935). Das Schicksal des deutschen Geistes im Ausgang seiner bürgerlichen Epoche. Zurich: Max Niehans.

Plessner, Helmuth (2001). "Wiedergeburt der Form im technischen Zeitalter.” In Politik-Anthropologie - Philosophie: Aufsätze und Vorträge, eds. Salvatore Giammusso and Hans-Ulrich Lessing, 71-86. Munich: Fink.

Plessner, Helmuth (2003). "Die Einheit der Sinne: Grundlinien einer Ästhesiologie des Geistes” [1923]. In Gesammelte Schriften III: Anthropologie der Sinne. Frankfurt am Main: Suhrkamp. (Extract translated as "The Objectivity of the Senses" by Matthew Bower https://www.academia.edu/4244238/Helmuth_Plessner_The_objectivity_of_the_senses).

Plessner, Helmuth (2011). "Rebirth of Form in the Technical Age" [1932]. Trans. Jonathan Blower. Art in Translation 3.1: 37-51.

Plessner, Helmuth (2014). “Review of Eric Voegelin's Race and State” [1934]. Trans. Timothy Matthew Hackett with Mario Marino. Graduate Faculty Philosophy Journal 35.1-2: 381-90. 